\title{
Determination of Accident Rates in the City of San Juan de Pasto in Southwestern Colombia
}

\author{
Fernando Jove Wilches ${ }^{1}$, Jorge Luis Argoty Burbano ${ }^{2}$ and Álvaro Rafael Caballero Guerrero ${ }^{3}$ \\ ${ }^{1}$ Department of Civil Engineering, Universidad de Sucre, Sincelejo, Sucre, Colombia. \\ ${ }^{2}$ Department of Civil Engineering, Universidad de Nariño, San Juan de Pasto, Nariño, Colombia. \\ ${ }^{3}$ Department of Civil and Environmental Engineering, Universidad del Norte, Barranquilla, Colombia.
}

ORCIDs: 0000-0002-2080-4036 (Fernando), 0000-0001-6661-1398 (Jorge), 0000-0002-3567-9135 (Álvaro)

\begin{abstract}
Among the most important aspects to monitor in traffic engineering, is the accident rate, which claims a high number of lives each year, leaves thousands of injured and causes considerable material damage. Hence, having reliable and upto-date information about traffic accidents occurring within a certain territory is essential for making decisions leading to the improvement of the road system. This document presents relevant information related to accidents that occurred in the city of San Juan de Pasto, department of Nariño, southwestern Colombia, during a period of 30 consecutive months between the years 2017 and 2019. For the organization of The accident rate data were considered the most important variables, among which we have: the date of occurrence of the accidents (month and year), the number of injured and deaths in accidents, the number and type of accidents, the classification of the victim involved in the accidents, the type of vehicle and the time intervals where the accidents occurred. Additionally, the calculation of morbidity, mortality and fatality rates, determined from part of the information collected, is presented. According to the results obtained, it could be established that the accident rates considered in the analysis presented the highest values during the noon and afternoon peak hours
\end{abstract}

Keywords: Accident rate, Urban roads, Morbidity rate, Mortality rate, Fatality rate

\section{INTRODUCTION}

Congestion and accidents are the two main consequences of the traffic problem; being the accident rate, vital and generating a high impact, since it means large casualties among the population, due to the result in deaths and injured, in addition to the economic loss [1]. According to the Instituto Mexicano del Transporte, the problem of road safety should be a matter of priority attention by governments, mainly for three types of reasons: humanitarian, public health and economic [2].

It is known that worldwide the number of people who lose their lives, or are crippled due to a traffic accident, is impressive [3]; This situation tends to increase over the years, since as the number of vehicles that make use of one or more of the modalities of the road transport system increases, the number of miles also increases vehicles that are traveled in different locations or sections of road, which results in greater exposure of the population to traffic accidents [4].
In order to give an idea of the magnitude of the problem, accident rates are used to compare their severity in different places during the same period of time or in the same place for different times. In this way, there are accident rates based on the population, the number of vehicles and the traffic. [3].

As a consequence of the great impact they generate on society, one of the most important studies in Traffic Engineering is that of accidents. The various solutions implemented based on the correct analysis of the problem, can yield very valuable results, saving many lives and avoiding a large number of injured, who might be crippled forever, as well as saving large economic losses [1].

Taking into account that traffic accidents depend on the limitations and complexities of human beings, their works, their coexistence relationships, as well as the laws of nature, it is possible to understand the difficulty of finding a true real cause for traffic accidents based on the data of the reports that are rendered on them [3].

Although it is true that $70 \%$ to $90 \%$ of these traffic accidents are due to human errors, there is no doubt that improving the road system and the vehicles themselves will reduce the occurrence of such errors [5], therefore, it is up to traffic and highway engineers to work to ensure that the street and highway system is designed and operated so that accident rates on streets and highways can be reduced. They also carry out with police officers and educators, a joint effort to ensure the observance of traffic regulations, such as those allusive to speed limits, the prohibition of driving while intoxicated, education regarding the responsibility of driving to the defensive, as well as the obligation to understand and obey traffic regulations [4].

The objective of this work was to determine some of the representative accident rates of the urban area of the city of San Juan de Pasto, located in the southwest of Colombia, in accordance with the registry of accidents that occurred within the period between January 2017 and June 2019. For this purpose, morbidity rates, mortality rate and fatality rate were determined, which were obtained based on the relationship between two variables, respectively: the number of injured with the total number of accidents, the number of deaths with the total number of accidents and the number of injured with the number of deaths. 
International Journal of Engineering Research and Technology. ISSN 0974-3154, Volume 13, Number 10 (2020), pp. 2611-2617 (C) International Research Publication House. https://dx.doi.org/10.37624/IJERT/13.10.2020.2611-2617

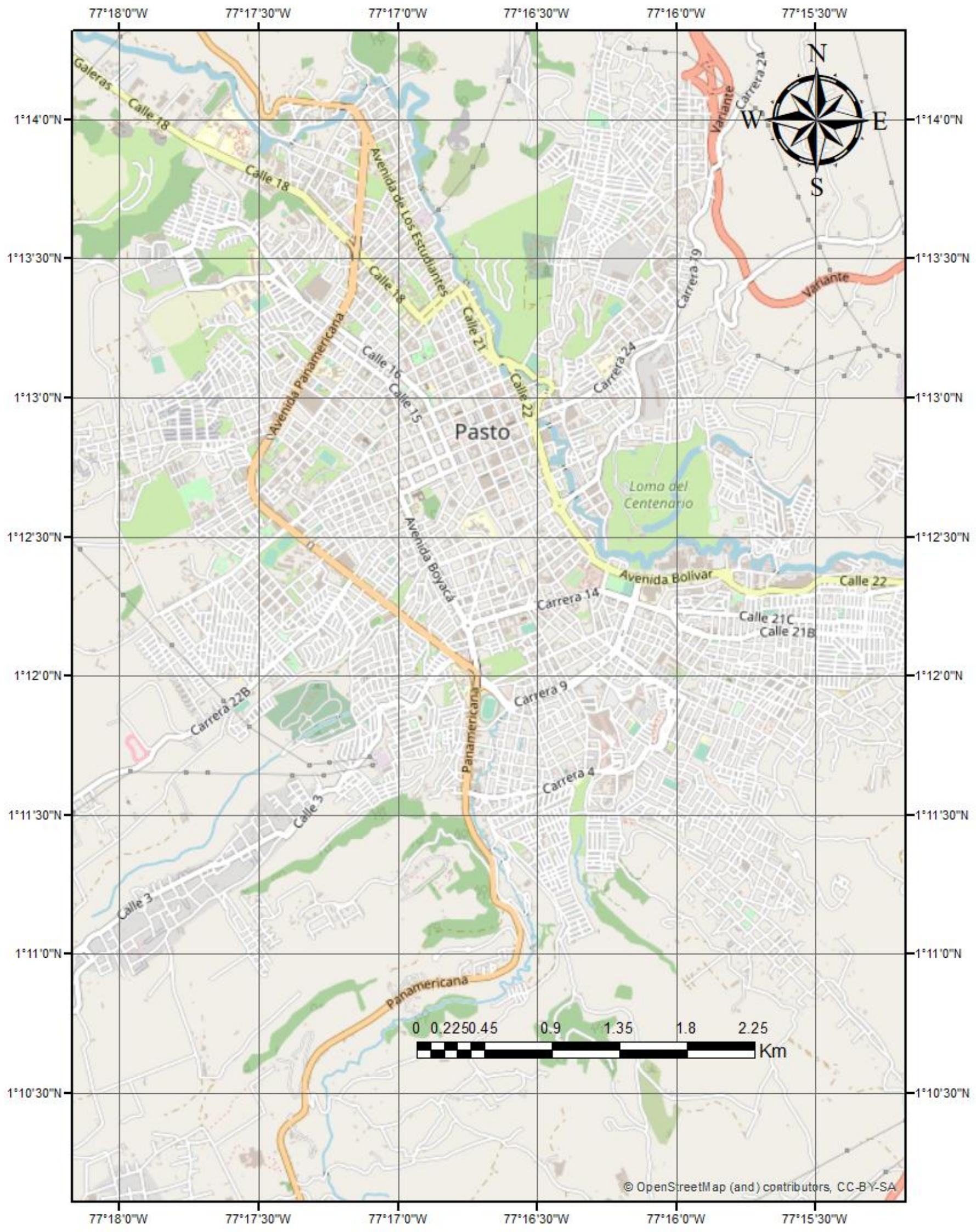

Fig 1. Location of San Juan de Pasto city in the department of Nariño (Colombia) 


\section{EXPERIMENTAL DESIGN, MATERIALS AND METHODS}

\section{II.I Study area description}

The Department of Nariño is located in the south west of Colombia, on the border with Ecuador. It limits to the North with the Department of Cauca, to the South with the Republic of Ecuador, to the East with the Department of Putumayo and to the West with the Pacific Ocean. The department is administratively organized into 13 sub-regions, being San Juan de Pasto, its capital [6].

The Municipality of San Juan de Pasto has an area of $1,181 \mathrm{~km}^{2}$ of which the urban area is $26.4 \mathrm{~km}^{2}$. It is the second largest city in the Pacific region after Cali. Its average temperature is 13.3 degrees Celsius. The municipality is located in the southwestern part of Colombia, in the middle of the Andes Mountains in the mountainous massif called Nudo de los Pastos and the city is located in the so-called Valle de Atríz, at the foot of the Galeras volcano. It limits to the north with the municipalities of Florida, Chachaguí and Buesaco; to the south with the Municipalities of Tangua, Funes and Putumayo; to the east with the Department of Putumayo and to the west with the municipalities of Florida, Tangua and Consacá. The landscape is mountainous, its height is 2,599 meters above sea level, it has average thermal floors, cold and we stop. Like the rest of the department, it has an important wealth of natural resources, biodiversity, different ecosystems, a variety of thermal floors and climates, and an important landscape offer [7].

Fig. 1 shows the location of the study area, which comprises the urban part of the San Juan de Pasto municipality, being able to observe the configuration of the internal roads of the city.

\section{II.II Study area description}

For the development of this work, the database named Traffic accidents DATA on urban roads in the city of San Juan de Pasto in Southwestern Colombia [8], deposited in the Mendeley data repository, was taken as a source. The data were obtained for a period of 30 consecutive months, which were extracted from several independent databases that contained accident records for maximum periods of one year. The selected data correspond to the years 2017, 2018 and part of 2019. For the creation of the database, the most relevant information was filtered and a comprehensive database was built. For this purpose, the columns represent all the variables obtained from the main databases or those that were derived from them. The rows show the periods indicated in year and month, which belong to the study period. The years and months were increasingly organized, beginning in January 2017 and ending in June 2019.

The first two columns were used to show the years and months of the period in which the data were collected. Then the number of accidents with serious property damage, the number of injuries and the number of people killed in traffic accidents are shown. The morbidity rates, the mortality rate and the fatality rate [9] were obtained by the relationship between two variables: the number of injured with the total number of accidents [10], the number of deaths with the total number of accidents and the number of wounded and number of dead [10].
The variables of the accident rate indicators are distributed based on temporal components [11], for the present case in months. For the calculation of these indicators, Equations 1, 2 and 3 [9], [10] were followed. The information obtained helps to describe the behaviour of the temporal component as an incident factor in morbidity and mortality due to Traffic Accidents.

Injurys $/$ accident $=\frac{I_{t}}{A} * 100$

Deaths $/$ accident $=\frac{M_{t}}{A} * 1000$

Fatality rate $=\frac{M_{t}}{M_{t}+I_{t}}$

where It is the total number of injured due to traffic accidents, $\mathrm{Mt}$ is the total number of deaths due to traffic and $\mathrm{A}$ is the total number of road traffic accidents.

The database also includes other independent variables that were collected during the construction process: the type of accident that occurred (collision or run over), the total number of accidents, the condition of the victim involved in the accident (companion, passenger or pedestrian), the types of vehicles involved in the accidents (motorcycles, cars, vans, buses and trucks) and the range of hours of the day in which the accidents occurred, for which the day was divided into five time intervals.

\section{RESULTS}

The data referring to traffic accidents were analyzed and the tables and figures were prepared, based on the information collected from the 30-month historical records, between the years 2017 and 2019.

Table 1 shows the number and type of accidents, the number and type of victims, and the total number of accidents, by year and month in which they occurred.

Fig. 2 shows the number of accidents classified by vehicle type and broken down month by month. The types of vehicles selected correspond to those that most frequently make use of urban roads in Colombia: motorcycles, automobiles, vans, buses and trucks.

In Fig. 3 the annual monthly average of the registered accidents is presented, for five time intervals (0:00-5:00, 5:00-10:00, 10:00-15:00, 15:00-20:00, 20:00-0:00).

In Fig. 4, the monthly records of the number of injured, deaths and total accidents are shown.

In Fig. 5, the morbidity rate (injured / accidents), the mortality rate (deaths / accidents) and the fatality rate determined based on the data analyzed are presented. 
International Journal of Engineering Research and Technology. ISSN 0974-3154, Volume 13, Number 10 (2020), pp. 2611-2617

(ㅇ International Research Publication House. https://dx.doi.org/10.37624/IJERT/13.10.2020.2611-2617

Table 1. Monthly distribution of accidents and type of victims involved

\begin{tabular}{|c|c|c|c|c|c|c|c|}
\hline \multirow[b]{2}{*}{ Year } & \multirow[b]{2}{*}{ Month } & \multicolumn{2}{|c|}{ Type of Accident } & \multicolumn{3}{|c|}{ Type of Victim } & \multirow{2}{*}{$\begin{array}{c}\text { Total } \\
\text { Accidents }\end{array}$} \\
\hline & & $\begin{array}{c}\text { Traffic } \\
\text { collisions }\end{array}$ & $\begin{array}{c}\text { Collisions involving } \\
\text { pedestrians }\end{array}$ & Companions & Passengers & Pedestrians & \\
\hline 2017 & January & 110 & 20 & 25 & 4 & 21 & 130 \\
\hline 2017 & February & 122 & 31 & 31 & 5 & 23 & 153 \\
\hline 2017 & March & 137 & 33 & 34 & 7 & 38 & 170 \\
\hline 2017 & April & 146 & 27 & 40 & 4 & 32 & 173 \\
\hline 2017 & May & 134 & 17 & 26 & 0 & 17 & 151 \\
\hline 2017 & June & 134 & 22 & 27 & 2 & 26 & 156 \\
\hline 2017 & July & 139 & 44 & 22 & 24 & 25 & 183 \\
\hline 2017 & August & 137 & 32 & 33 & 24 & 36 & 169 \\
\hline 2017 & September & 129 & 25 & 32 & 2 & 28 & 154 \\
\hline 2017 & October & 134 & 28 & 30 & 3 & 29 & 162 \\
\hline 2017 & November & 118 & 22 & 15 & 3 & 21 & 140 \\
\hline 2017 & December & 126 & 20 & 15 & 0 & 21 & 146 \\
\hline 2018 & January & 102 & 8 & 14 & 15 & 9 & 110 \\
\hline 2018 & February & 114 & 22 & 16 & 5 & 22 & 136 \\
\hline 2018 & March & 112 & 21 & 27 & 5 & 19 & 133 \\
\hline 2018 & April & 149 & 14 & 25 & 2 & 15 & 163 \\
\hline 2018 & May & 91 & 23 & 44 & 18 & 54 & 114 \\
\hline 2018 & June & 121 & 15 & 34 & 4 & 16 & 136 \\
\hline 2018 & July & 85 & 23 & 12 & 3 & 21 & 108 \\
\hline 2018 & August & 115 & 24 & 33 & 1 & 28 & 139 \\
\hline 2018 & September & 105 & 27 & 19 & 1 & 28 & 132 \\
\hline 2018 & October & 121 & 21 & 31 & 6 & 21 & 142 \\
\hline 2018 & November & 96 & 17 & 14 & 2 & 17 & 113 \\
\hline 2018 & December & 114 & 15 & 263 & 55 & 240 & 129 \\
\hline 2019 & January & 67 & 12 & 14 & 1 & 13 & 79 \\
\hline 2019 & February & 86 & 11 & 22 & 2 & 14 & 97 \\
\hline 2019 & March & 102 & 9 & 19 & 6 & 12 & 111 \\
\hline 2019 & April & 86 & 16 & 17 & 1 & 20 & 102 \\
\hline 2019 & May & 83 & 17 & 24 & 4 & 18 & 100 \\
\hline 2019 & June & 76 & 14 & 10 & 5 & 16 & 90 \\
\hline
\end{tabular}


International Journal of Engineering Research and Technology. ISSN 0974-3154, Volume 13, Number 10 (2020), pp. 2611-2617

(ㅇ International Research Publication House. https://dx.doi.org/10.37624/IJERT/13.10.2020.2611-2617

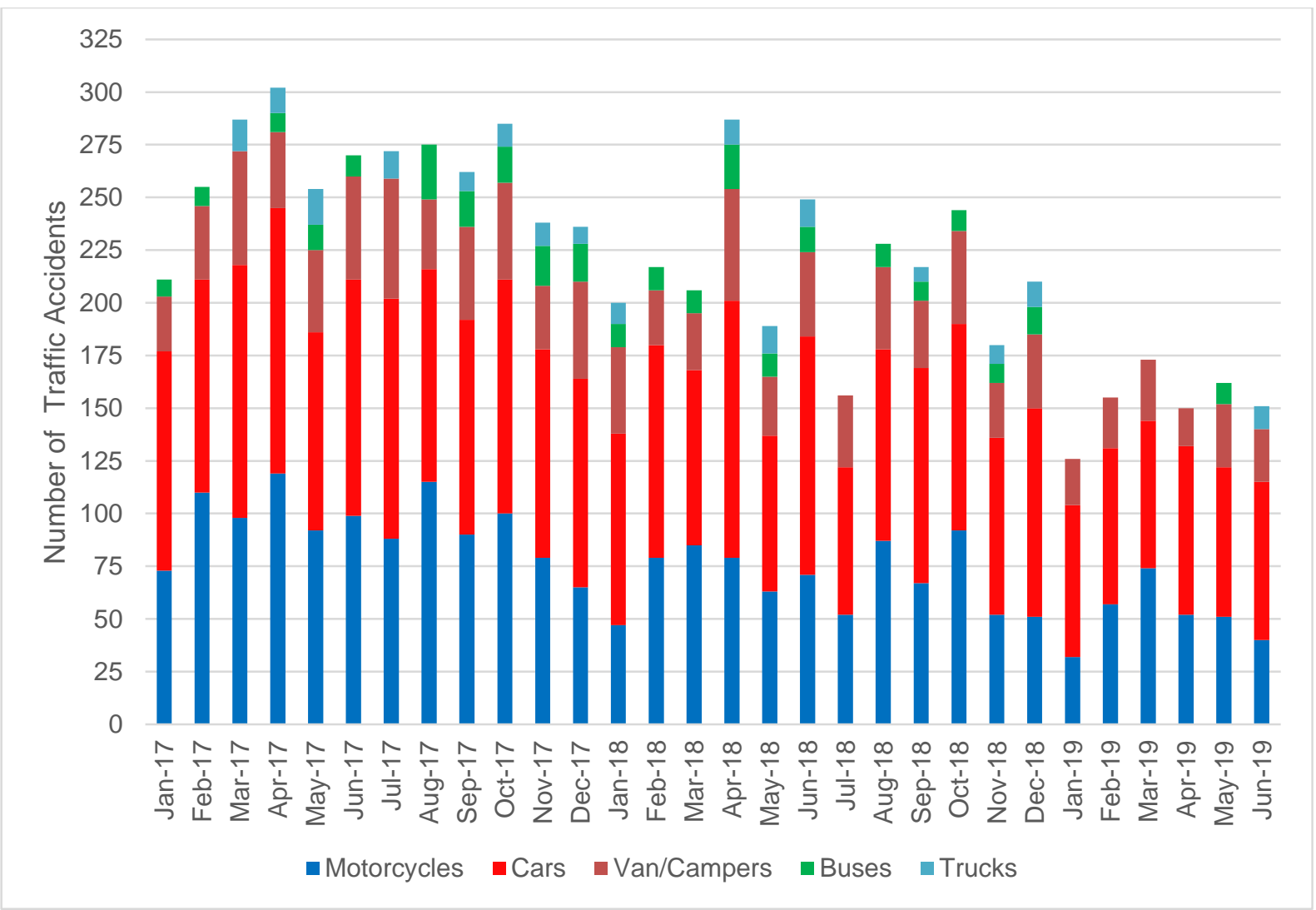

Fig. 2. Monthly distribution of accidents discriminated by type of vehicle

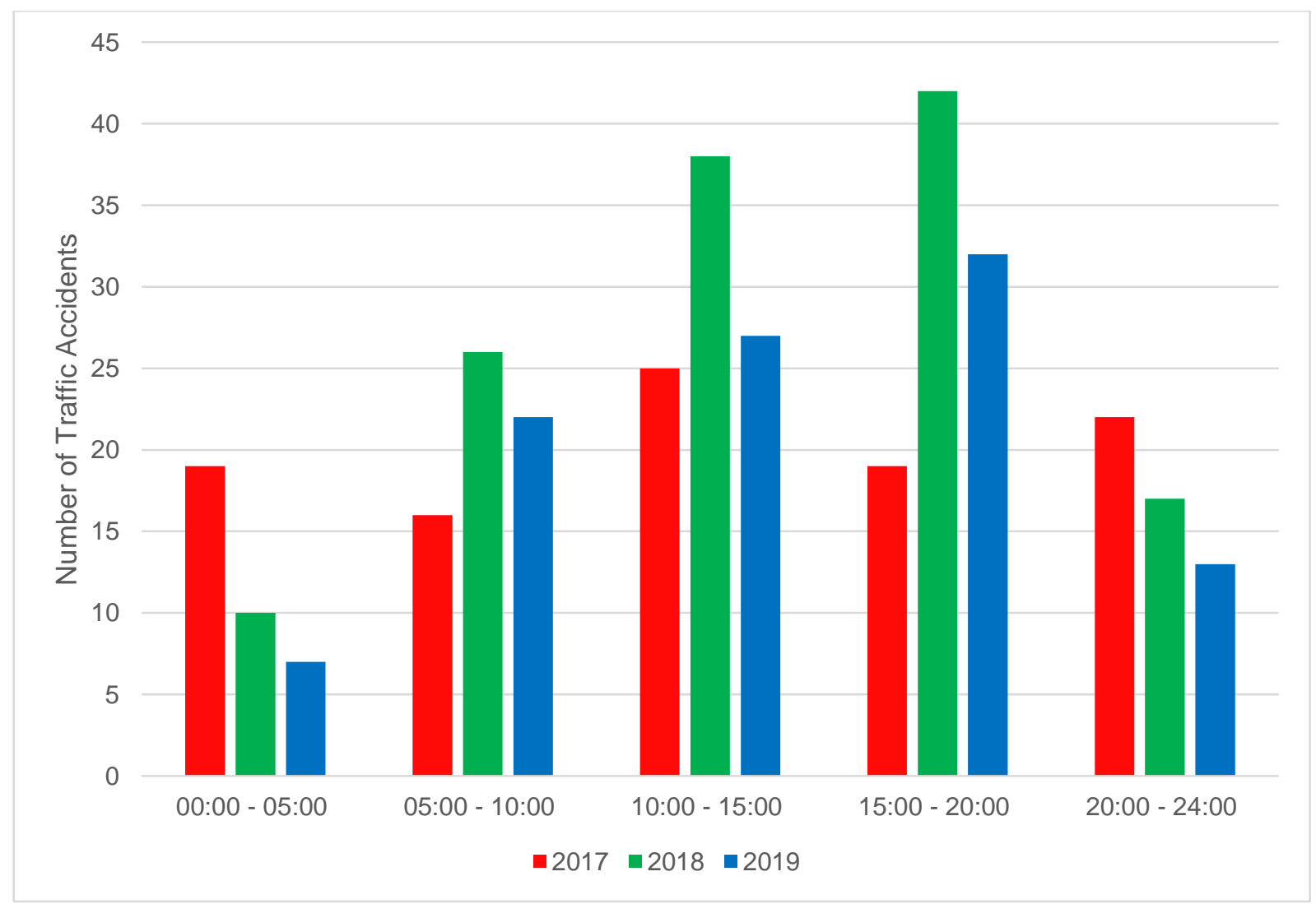

Fig. 3. Annual monthly average accidents by hourly range 


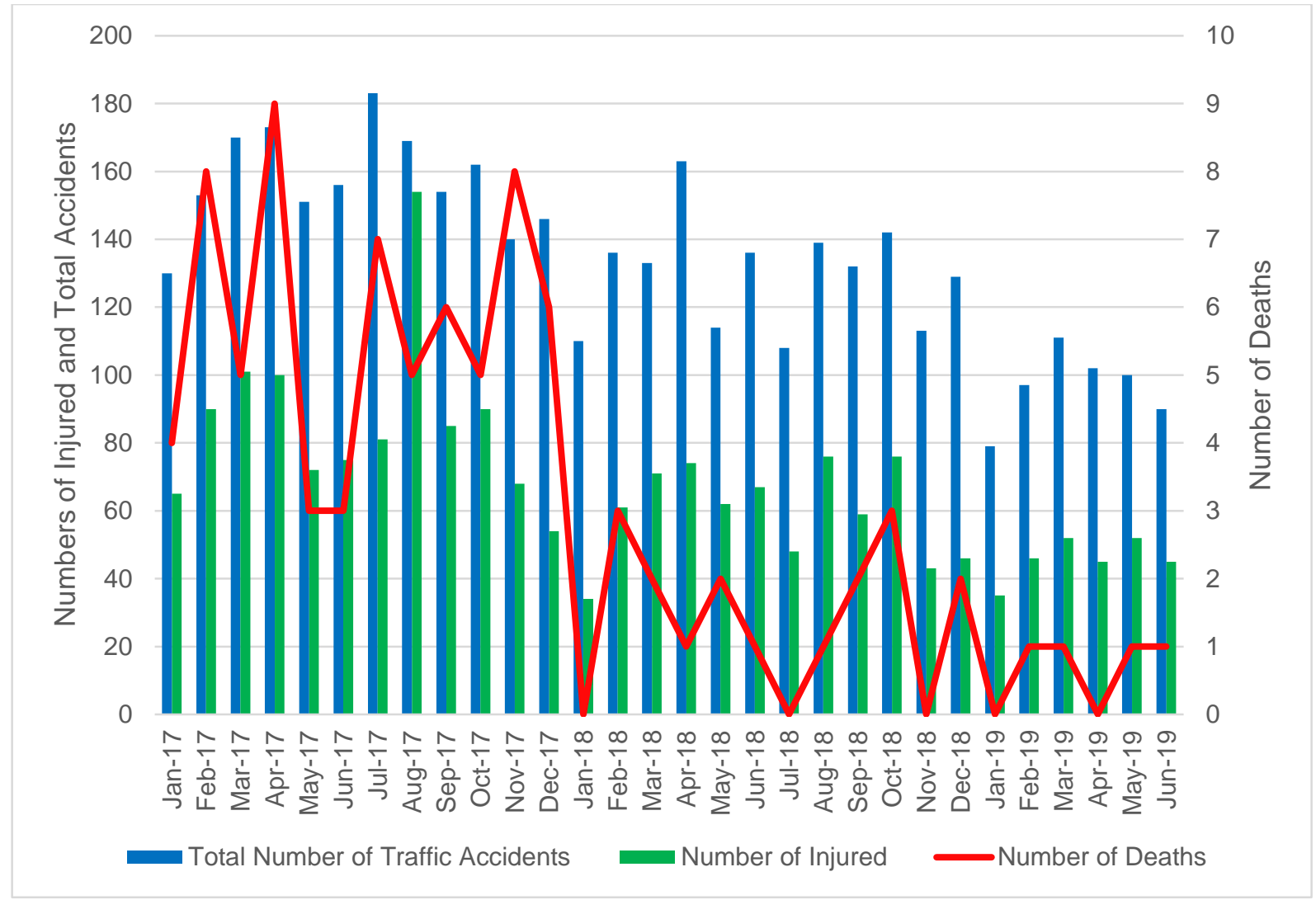

Fig. 4. Monthly distribution of injured, deaths and total number of accidents

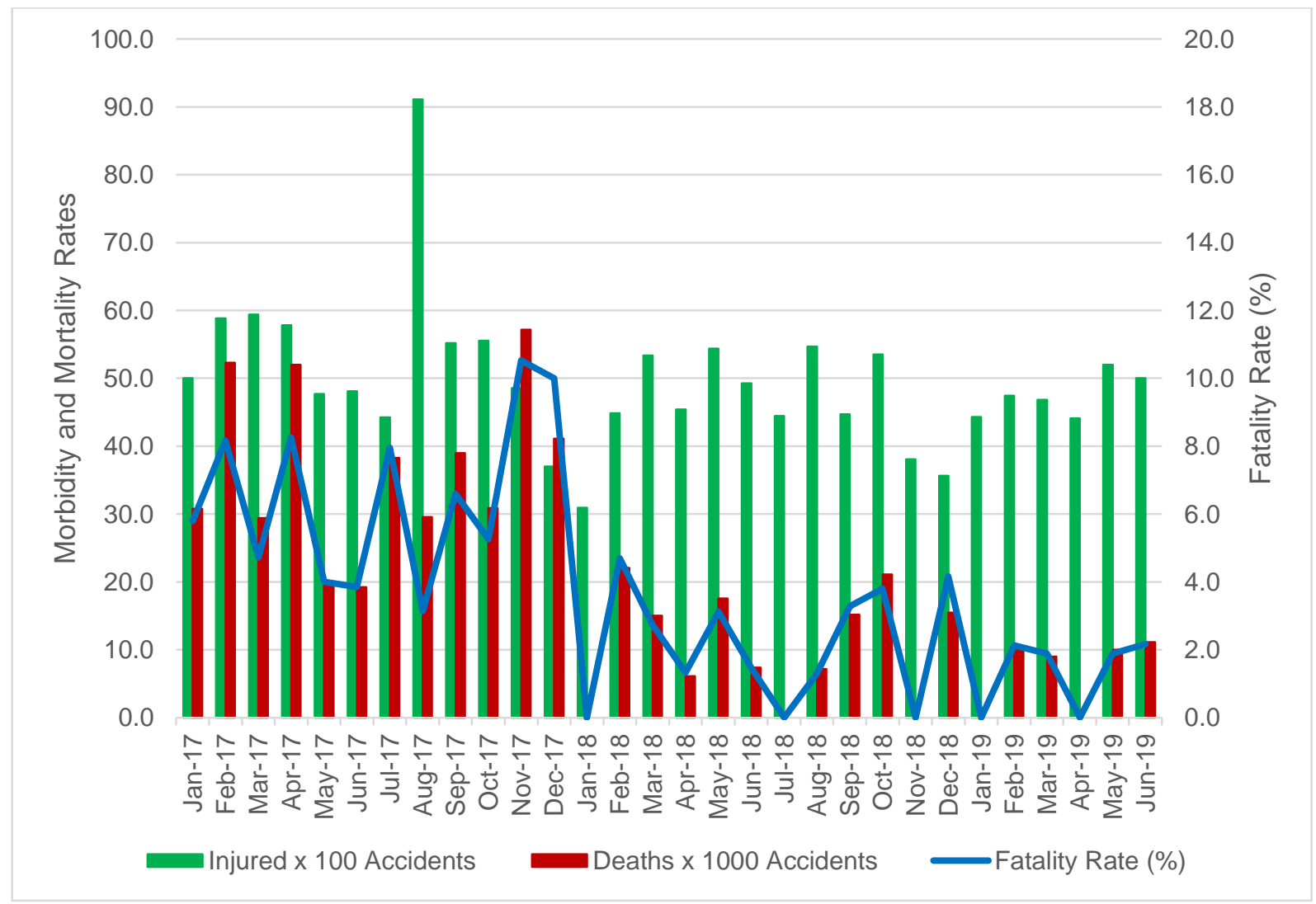

Fig. 5. Monthly morbidity, mortality and fatality rates 


\section{CONCLUSION}

According to the results obtained, it could be observed that during 2017 there were a greater number of accidents, deaths and injuries, compared to those observed in 2018 and 2019, where a noticeable decrease was observed in the values obtained for these attributes. On the other hand, the accident rates considered in the analysis presented the highest values during the peak hours of noon and afternoon.

\section{REFERENCES}

[1] Cal y Mayor R and Cárdenas J, "Ingeniería de tránsito", 8th edition, Alfa Omega Grupo editor, México, 2007.

[2] Mendoza A, Quintero F and Mayoral E. Secretaria de Comunicaciones y Transportes, Instituto Mexicano del Transporte. Seguridad Vial en Carreteras. Publicación Técnica No. 224, Sanfandila, Querétaro, México, 2003.

[3] Crespo, C, Vias de comunicacion: Caminos, ferrocarroles, aeropuestos, puentes y puertos, Tercra edicion, Limusa, Mexico, 2004.

[4] N. Garber and L. Hoel, "Ingeniería de tránsito y carreteras", tercera edition, Thomson editores, México, (2005).

[5] Instituto of Transportation Engineers. Traffic Engineering Handbook. Fifth edition, James L. Pline Editor, Washington, D.C., 1999.

[6] Universidad de Nariño, Caracterización Social y Económica del Departamento de Nariño. http://sipersn.udenar.edu.co:90/sipersn/docs/ipp/ISSE/Car acterizacionSocialyEconomicadelDepartamentodeNarino. pdf, 2014 (accessed 10 August 2020).

[7] Alcaldía de Pasto, Plan Territorial de Salud. http://www.pasto.gov.co/phocadownload/documentos201 2/salud/plan_territorial_de_salud_2012-2015.pdf, 2012 (accessed 10 August 2020).

[8] Jove Wilches, F; Contreras Sierra, E (2020), "Dataset: Traffic accidents DATA on urban roads in the city of San Juan de Pasto in Southwestern Colombia", Mendeley Data, V1, doi: 10.17632/f7w3gst2p2.1

[9] Farchi, S., Molino, N., Giorgi Rossi, Piero, B., Krzyzanowski, M., Dalbokova, D., Kim, R., European Road Accident Indicator Working Group, 2006. Defining a common set of indicators to monitor road accidents in the European Union. BMC Public Health 6, 183. https://doi.org/10.1186/1471-2458-6-183.

[10] A.R. Gómez, V. Orbe, Y. Campos, Morbilidad y mortalidad por accidentes de tránsito según componentes temporales, Ecuador. Revista KILLKANA Salud y Bienestar. $\quad 3 \quad$ (1) (2019) 9-16. https://doi.org/10.26871/killcana_salud.v3i1.246.

[11] A.F. Algora, M. Russo, P.R. Suasnavas, P. Merino, A.R. Gómez. Tendencias de los accidentes de tránsito en Ecuador: 2000 - 2015. Revista Gerencia y Políticas de Salud. $\quad 16 \quad$ (33) (2017) 52-58. https://doi.org/10.11144/Javeriana.rgps16-33.tate 